\title{
地場産農産物に対する消費者の選好
}

\author{
大西 茂 1 **田中 勝也 ${ }^{2)}$
}

\section{Consumers' Preferences in Locally-grown Farm Products}

\author{
Shigeru Ohnishi ${ }^{1) *} \&$ Katsuya Tanaka ${ }^{2)}$
}

This paper aims to clarify the consumers' preferences in locally-grown farm products, such as rice, vegetables, and fruits. From the viewpoint of ensuring sustainable consumption and production patterns compatible with SDGs, local food production and consumption will be required more than ever before. The results of this study show that consumers' preferences depend on the product in question. For example, the most important characteristic is "taste" for rice, and "price" for vegetables and fruits. It is also revealed that consumer is not aware of supporting local environmental benefits through purchasing locally-grown food. The implication here is there is a potential for promoting locally-grown foods. As a reflection of consumers lifestyle recently, it is statistically shown that high health consciousness urges consumers to buy vegetables, rather than rice and fruits.

SDGs seek a plan of action to transform everyone into a sustainable society. One easy action is to strengthen consumers' purchase of locally-grown food products. The findings of this study also offers suggestions for formulating effective strategies for promoting locallygrown food products.

\section{キーワード：地場産農産物，消費者選好，購買行動，栽培経験，SDGs}

\section{1. はじめに}

2015 年に国連で採択された持続可能な開発目標 (SDGs) は，持続可能な社会のために必要な 17 の目 標を設定しており，とりわけ目標 12 には「持続可能 な生産消費形態を確保する」ことがアジェンダに挙 ゲられている。

近年, 地場産農産物の消費は, 食料自給率の向上, 食生活の見直し，環境保全，地域経済の活性化など， 生産者や消費者だけでなく，社会にとっても望まし い生産と消費と考えられ，この目標 12 に対する具体 的なアクションとして期待されている1. そのため, 地場産農産物の地場消費を意味する「地産地消」の 促進が求められる.

また，この動きとは別に，「倫理的消費（エシカル 消費)」といら考え方が 1980 年代から北欧を中心に 広がりを見せている，倫理的消費について，消費者
庁の「消費者基本計画」では「地域の活性化や雇用 なども含む，人や社会・環境に配慮した消費行動」 と定義している。国内でも，これを促進させるため に消費者庁により「『倫理的消費』調査研究会」が 2015 年に立ち上げられ，SDGs の目指す持続可能な 社会と認識を共有している（消費者庁，2017: p. 1).

既述のような近年の動向から, 地産地消を促進さ せる必要性が改めて求められている. Micheletti (2003 : pp. 2-3) は, 日常的な消費の選択に沶いて, 一人一人の消費は微少であっても，それらが集合化 することにより，社会を変えることができる，と述 ベている．消費の選択如何では持続可能な社会へと 仕組みを変える可能性があり（消費者庁，2017：p. 25)，地産地消はその社会へと変える選択肢の一つで あると考えられている。

本研究の目的は, 地場産農産物の購買促進に向け て，消費者の選好を明らかにすることである，次節

\footnotetext{
1) 滋賀大学環境総合研究センター; Research Center of Sustainability and Environment, Shiga University

2) 滋賀大学環境総合研究センター・経済学部; Research Center of Sustainability and Environment and Faculty of Economics, Shiga University

*E-mail: shigeru-onishi@biwako.shiga-u.ac.jp (地域農林経済学会 
で詳しく述べるように，地場産農産物の購買促進に 関しては多くの研究が存在する。しかしながら，そ れらの多くは特定の農産物に限定したものであり， 複数品目を対象とした研究は限定的である. 本研究 は, 米, 野菜, 果物を対象品目として共通の分析モ デルにより同時に分析することが特徵である.

本研究の対象は, 滋賀県野洲市である. 同市は琵 琶湖の南東に位置する面積 80 平方 $\mathrm{km}$, 人口約 5 万 1 千人（2019 年 9 月現在）の自治体である. 同市は 近江平野の自然環境を生かして米作りが盛んであり, また，その立地から京都，大阪のベッドタウンとし ての転入も進んでいる.

本研究では, 同市に居住する成人 4,000 人に対し て市民意向調査を実施し, 地産地消に関する購買行 動を含め, 市民の満足度や市政に関する質問につい て 819 人より回答を得た. その内容は, 回答者の価 值観やライフスタイルを含めた多様な個人属性が調 查されて打り, 野洲市との共同研究として地産地消 を促進させるための要因分析に活用が期待できる.

\section{2. 先行研究}

地場産農産物の購買促進に関しては多くの研究が ある. 牧山・三富（2004）は購入者の属性や意識を スーパー直売コーナーの購入者に対して調査を実施 し, 地場産農産物の購入者確保のためには, 地場産 といらイメージだけではなく品質といら実態を伴っ た農産物を用意する必要があるとしている. 同様に 来店者を対象として，山本他（2009）は，消費者が 地場産農産物を評価する要因, 抢よび妥当な価格プ レミアムの水準について, 表明選好法により分析し ている. その結果, 高い経済評価を与える要因とし て消費者意識では「より詳細な産地名を重視する」 「安全性が高そう」などを抽出している，また，支払 意志額 (WTP) については一般野菜よりも 1 割弱高 いといら結果を得ている. 地場産農産物の WTPが 一般野菜よりも高くなる要因として, Thilmany et al. （2008）は，地元農家の支援や地域経済の活性化が 相対的に重要であることを明らかにした。

大庭他（2006）は, 実際の購買行動への影響を地 元との関わり合いの程度や農への関心・関わりから 分析し,「安全な野菜志向」が強いこと,「農とのつ ながり」も購買促進に有効であることを示唆してい
る. Brown（2003）も地場産農産物の消費者選好の 要素として, 家族内に農作業経験者がいることや環 境活動への参加は農産物の価格プレミアムを受容す ることを報告している.

地場産農産物の購買促進が環境保全につながるこ とから, 西村他 (2012) は, 滋賀県の「魚のゆりか ご水田」が生物多様性保全に寄与するといら知識を 消費者が獲得することにより, その水田で栽培され た米の購買意志を強めるといらこと, また, 徳永他 （2015）は地元農産物の購入を環境配慮行動と捉え, その行動要因として旬野菜の栄養素に関する情報提 供や $\mathrm{CO}_{2}$ 排出量削減情報の提示が, 消費者の意識改 革に有効であることを明らかにしている.

マーケティングの視点から, 藤島・岩崎 (2010) は, 性別・年代などの人口統計的要因よりも, 消費 者の食に関するライフスタイルを重視した農産物の ダイレクト・マーケティングの重要性を指摘してい る. また, Zepeda and Li (2006) は, 省エネや健康, 価格を訴求した販促キャンペーンは消費者に伝わる ものの購買行動に結びつきにくく, 地場産農産物を 調理する楽しみを訴求する方が効果的である，と分 析している.

これらの先行研究に抢ける調査の多くは, 最終的 に地場産農産物の購買を促進させる要因を規定する ことを目的としたものであり, 調査内容も地場産農 産物の購入状況やその購入理由を尋齐, その背後に ある要因として研究者の仮定する消費者の属性や経 験を質問するケースが多い。しかし，本調査では， 多くの先行研究で見られる特定の農産物のみを対象 とせず，米・野菜・果物を同時に調査しているのが 特徵である. このため, 購入促進要因に関してょり 実務的な商品間の差異が分析できる。 また，後述す る同時調查から, 回答者の広範な個人属性を利用し て, 先行研究にはない有意な説明变数が見いだされ る可能性がある.

\section{3. 調査の概要}

本調査は 2019 年 2 月に, 野洲市内に居住する全 成人から無作為に抽出された 4,000 人を対象に, 郵 送により実施した。回答が期日までに返送されたの は 819 件, 回収率は $20.5 \%$ であった。

調査票では, 地場産農産物の購入頻度, 購入理由, 
表 1. 回答者の属性と野洲市との比較（構成比率）

\begin{tabular}{|c|c|c|c|c|}
\hline \multirow{2}{*}{ 属性 } & \multirow{2}{*}{ 水準 } & \multirow{2}{*}{ 人数 } & \multicolumn{2}{|c|}{ 構成比率 } \\
\hline & & & 回答者 & 野洲 1) \\
\hline \multirow[t]{2}{*}{ 性別 } & 男性 & 396 & $49.9 \%$ & $49.6 \%$ \\
\hline & 女性 & 397 & $50.1 \%$ & $50.4 \%$ \\
\hline \multirow[t]{4}{*}{ 年齢 } & 20-30 歳代 & 150 & $19.0 \%$ & $28.2 \%$ \\
\hline & 40-50 歳代 & 239 & $30.3 \%$ & $33.2 \%$ \\
\hline & 60-70 歳代 & 343 & $43.4 \%$ & $30.3 \%$ \\
\hline & 80 歳以上 & 58 & $7.3 \%$ & $8.3 \%$ \\
\hline \multirow[t]{7}{*}{ 年収 } & 200 万未満 & 50 & $8.0 \%$ & - \\
\hline & 200-400 万未満 & 197 & $31.6 \%$ & - \\
\hline & 400-600 万未満 & 133 & $21.3 \%$ & - \\
\hline & 600-800 万未満 & 113 & $18.1 \%$ & - \\
\hline & 800-1,000 万未満 & 63 & $10.1 \%$ & - \\
\hline & 1,000-1,200 万未満 & 38 & $6.1 \%$ & - \\
\hline & 1,200 万以上 & 29 & $4.7 \%$ & - \\
\hline \multirow[t]{5}{*}{ 職業 } & 第 1 次産業 & 16 & $2.1 \%$ & $2.2 \%$ \\
\hline & 第 2,3 次産業 & 378 & $49.0 \%$ & $54.0 \%$ \\
\hline & 公務員・教員 & 39 & $5.1 \%$ & $4.7 \%$ \\
\hline & 無職 & 319 & $43.8 \%$ & $39.1 \%$ \\
\hline & その他 & 19 & $2.5 \%$ & - \\
\hline
\end{tabular}

1) 野洲市構成比率データ出所 :

- 年齢構成 : 住民基本台帳（H29.3.31 現在）

- 職業構成: H27 国勢調査（産業大分類別就業者数）

- 無職 $=$ 人口 - 就業者数 -20 歳未満の数

購入場所をそれぞれ米，野菜，果物ごとに質問した また，関連する項目として回答者の自家菜園なぞで の栽培経験も尋齐た。

「地場産」の説明では「扮扮よそ野洲市もしくはそ の周辺地域で収穫された農産物」である旨を文章で 提示した. これは内藤（2006:pp.47-48）の「行政 区域でいえば，広くても同一市町村あるいは同一都 道府県内の範囲とするのが妥当であろら」とする説 を支持し, さらに, 調查地域近辺では隣接市町村で 收檴された農産物も直売所で多く販売されている. 以上のことを勘案し「地場産」の定義を定めた。ま た，回答者が地場産農産物のアンケートであること を認識するように各商品の設問毎に「地場産」の文 字を太字で示した

表 1 亿回答者の属性を示す。同表には, 野洲市全 体の性別，年齢，職業に関する構成比率も併記した.
表 2. 変数の定義

\begin{tabular}{|c|c|c|}
\hline & 変数 & 定義 \\
\hline \multicolumn{3}{|c|}{ 目的変数 } \\
\hline 購入 & 頻度 & $\begin{array}{l}\text { 日常的に購入 }=3, \text { たまに購入 }=2, \text { ごく } \\
\text { たまに購入 }=1 \text {, 購入しない・わからない } \\
=0\end{array}$ \\
\hline \multicolumn{3}{|c|}{ 説明変数 } \\
\hline \multicolumn{3}{|c|}{ 購入理由（3 選択肢まで可） } \\
\hline 安 & 全 & 安全だから=1, そらでない $=0$ \\
\hline & 援 & $\begin{array}{l}\text { 地元農業を応援したい＝1，そらでない } \\
=0\end{array}$ \\
\hline 価 & 格 & 価格が手頃だから＝1，そらでない＝0 \\
\hline 環 & 境 & $\begin{array}{l}\text { 地域環境に貢献したい＝1，そうでない } \\
=0\end{array}$ \\
\hline 食 & 味 & 食味が良いから=1，そらでない＝0 \\
\hline 信 & 頼 & 信頼できるから=1, そらでない=0 \\
\hline 新 & 鮮 & 新鮮だから=1, そらでない $=0$ \\
\hline
\end{tabular}

購入場所（択一式）

\begin{tabular}{|c|c|}
\hline ーパー & おるにスーパーで購入 $=1$, それ以外 $=0$ \\
\hline 直売所 & おもに直売店で購入 $=1$, それ以外 $=0$ \\
\hline 地元小売店 & $\begin{array}{l}\text { おもに地元小売店で購入 }=1 \text {, それ以外 } \\
=0\end{array}$ \\
\hline 動販売 & おもに移動販売で購入 $=1$, それ以外 $=0$ \\
\hline $\begin{array}{l}\text { その他の } \\
\text { 場所 }\end{array}$ & おもに上記以外で購入 $=1$, 左記以外 $=0$ \\
\hline 無 & $\begin{array}{l}\text { 購入頻度で購入しない・わからない=0 } \\
\text { それ以外 }=1\end{array}$ \\
\hline & $\begin{array}{l}\text { 販売目的での作業 }=3 \text {, 自給自足程度の作 } \\
\text { 業 }=2 \text {, 家庭菜園程度の作業 }=1 \text {, 作業経 } \\
\text { 験はない }=0\end{array}$ \\
\hline
\end{tabular}

人口動態要因以外飞も，本研究と同時に調査された 野洲市の市民意向調査には環境や省エネ意識，地域 への愛着度，健康管理の現状と意識，防犯・防災一 の考方方，地域社会へ貢献の意向，交通インフラの 利用状況，近隣コミュニティーの親密さの程度，自 己啓発活動への意欲，自治会活動への参画度合なぞ, 極めて広範なデータが存在する。

以上のような調查項目から，分析の指標としての 個人属性データについては，先行研究に関わらず市 民意向調査の一部結果も含めて分析する. 
表 3. 記述統計量（平均）

\begin{tabular}{lccc}
\hline \hline \multicolumn{1}{c}{ 変数 } & 米 & 野菜 & 果物 \\
\hline 目的変数 & & & \\
購入頻度 & 1.412 & 1.590 & 1.041 \\
(標準偏差) & $(1.338)$ & $(1.067)$ & $(0.995)$ \\
説明変数 & & & \\
購入理由 & & & \\
安 全 & 0.236 & 0.331 & 0.222 \\
応 援 & 0.169 & 0.210 & 0.157 \\
価 格 & 0.203 & 0.300 & 0.186 \\
環 境 & 0.028 & 0.022 & 0.024 \\
食 味 & 0.175 & 0.125 & 0.150 \\
信 頼 & 0.209 & 0.178 & 0.139 \\
新 鮮 & 0.160 & 0.525 & 0.380 \\
購入場所 & & & \\
ス一パー & 0.253 & 0.452 & 0.279 \\
直売所 & 0.107 & 0.245 & 0.226 \\
地元小売店 & 0.018 & 0.018 & 0.013 \\
移動販売 & 0.000 & 0.002 & 0.002 \\
その他の場所 & 0.160 & 0.015 & 0.014 \\
購入有無ダミ一 & 0.577 & 0.779 & 0.605 \\
栽培経験 & & & \\
栽培経験 & & & \\
(標準偏差) & 0.762 & 0.775 & 0.778 \\
\hline & $0.778)$ & $(0.778)$ \\
\hline
\end{tabular}

表 4. 商品別購入頻度

\begin{tabular}{lccccc}
\hline \hline & $\begin{array}{c}\text { 日常的に } \\
\text { 購入 }\end{array}$ & $\begin{array}{c}\text { たまに } \\
\text { 購入 }\end{array}$ & $\begin{array}{c}\text { ごくたま購入 } \\
\text { わからない }\end{array}$ & $\begin{array}{c}\text { 購入しない. } \\
\text { わが }\end{array}$ \\
\hline 米 & 255 & 101 & 65 & 310 & 731 \\
野菜 & 166 & 265 & 142 & 163 & 736 \\
果物 & 59 & 203 & 184 & 291 & 737 \\
\hline
\end{tabular}

\section{4. 調査の集計結果}

まず,アンケートの質問を構成する変数の定義 (表 2）と記述統計量（表 3) を示す. 目的变数となる地 場産農産物に対する購入頻度, 扣よび地場産農産物 飞対する購入理由, 購入場所の各説明変数は, 栽培 経験を除き，米，野菜，果物ごとに調査されている.

このため, 回答者によっては, いずれかの農産物 で目的変数に欠損があり, 分析対象となる件数が商
表 5. 商品別購入理由

\begin{tabular}{lrrrrrr}
\hline \hline & \multicolumn{3}{c}{ 米 } & \multicolumn{2}{c}{ 野菜 } & \multicolumn{2}{c}{ 果物 } \\
\hline 購入理由 & $\mathrm{N}$ & 比率 & \multicolumn{1}{c}{$\mathrm{N}$} & \multicolumn{1}{c}{ 比率 } & $\mathrm{N}$ & \multicolumn{1}{c}{ 比率 } \\
\hline 安全 & 165 & $19.5 \%$ & 238 & $19.4 \%$ & 160 & $17.4 \%$ \\
応援 & 121 & $14.3 \%$ & 151 & $12.3 \%$ & 113 & $12.3 \%$ \\
価格 & 134 & $15.8 \%$ & 216 & $17.6 \%$ & 134 & $14.5 \%$ \\
環境 & 20 & $2.4 \%$ & 16 & $1.3 \%$ & 17 & $1.8 \%$ \\
食味 & 126 & $14.9 \%$ & 90 & $7.3 \%$ & 108 & $11.7 \%$ \\
信頼 & 148 & $17.5 \%$ & 128 & $10.4 \%$ & 107 & $11.6 \%$ \\
新鮮 & 113 & $13.3 \%$ & 378 & $30.8 \%$ & 274 & $29.7 \%$ \\
その他 & 21 & $2.5 \%$ & 11 & $0.9 \%$ & 9 & $1.0 \%$ \\
$\mathrm{~N}$ 合計 & \multicolumn{2}{c}{848} & \multicolumn{2}{c}{1228} & \multicolumn{2}{c}{992} \\
\hline
\end{tabular}

品ごとに異なってくる．今回は，米・野菜・果物の 購入頻度への回答者数をそれ艺れの分析対象件数と した. 表 4 に，調査票での選択肢とした購入頻度の 単純集計を商品別に示す。これらの商品ごとの合計 值が分析対象件数である.な拉，「購入しない・わか らない」とした回答者の購入理由はすべで0”をデー タ入力値とした。 また，購入理由は 3 選択肢まで可 とした ${ }^{2}$.

表 5 には，商品別の購入理由を示した。この表か ら, 商品ごとに購入理由の類似点と相違点が明らか になる. 比較のため, 各購入理由の回答数を比率で 示している. 野菜と果物は新鮮さの割合が他の購入 理由に比べ顕著である. 米は各購入理由の比率が同 程度である。また， 3 商品に共通する点は，環境の 割合が他の購入理由に比べ極めて低いことである. 地場産農産物に対する消費と地域環境への貢献との 結びつきについては，あまり意識されていないこと がわかる。

表 6 は, 各商品が主にどこで購入されているのか, その割合を示している．各商品ともスーパーが主た る購入先であるが，野菜，果物については直売所の 利用も多い。米はスーパーと直売所だけでなく，そ の他からの購入比率も多く, 主に 3 か所から買い求 めていることがわかる．な拉，分析時点での移動販 売は米 0 件, 野菜・果物各 1 件であったため, その 他の場所に含めた.

最後に, 栽培経験に扣ける集計值を表 7 亿示す. 回答者の約 6 割が何らかで栽培経験を有しているこ 
表 6. 商品別購入場所

\begin{tabular}{lrrrrrr}
\hline \hline & \multicolumn{2}{c}{ 米 } & \multicolumn{2}{c}{ 野菜 } & \multicolumn{2}{c}{ 果物 } \\
\hline \multicolumn{1}{c}{ 購入場所 } & $\mathrm{N}$ & 比率 & \multicolumn{1}{c}{$\mathrm{N}$} & 比率 & $\mathrm{N}$ & 比率 \\
\hline スーパー & 173 & $46.5 \%$ & 280 & $61.7 \%$ & 175 & $52.2 \%$ \\
直売所 & 73 & $19.6 \%$ & 152 & $33.5 \%$ & 142 & $42.4 \%$ \\
地元小売店 & 12 & $3.2 \%$ & 11 & $2.4 \%$ & 8 & $2.4 \%$ \\
その他の場所 & 114 & $30.6 \%$ & 11 & $2.4 \%$ & 10 & $3.0 \%$ \\
$\quad \mathrm{~N}$ 合計 & \multirow{2}{*}{372} & \multicolumn{2}{c}{454} & \multicolumn{2}{c}{335} \\
\hline
\end{tabular}

表 7. 栽培経験別件数

\begin{tabular}{lcccc}
\hline \hline & 販売目的 & 自給自足 & 家庭菜園 & 経験なし \\
\hline $\mathrm{N}$ & 25 & 76 & 317 & 281 \\
比率 & $3.6 \%$ & $10.9 \%$ & $45.4 \%$ & $40.2 \%$ \\
\hline
\end{tabular}

とがわかる，農業センサスによれば，平成 27 年の兼 業農家率（販売農家数に占める兼業農家数）は, 全 国平均で 66.7\%であるが野洲は 81.1\%と高くなって 打り，此較的家庭菜園を含め栽培経験を得やすい環 境にあると考光られる。この栽培経験の違いが地場 産農産物の購入行動に影響することも考兄られるた め，次節の分析モデルに含めることとした.

\section{5. 分析手法と結果}

本研究に打沙調査は, 地場産農産物の購入促進 要因を購入頻度に影響を与兄る要因によって規定し ようというものである。すなわち，購入頻度の多い 人は，どのような理由や，どの場所で購入している のか，或いは，ぞのような個人属性やライフスタイ ルをもっているのか，を分析する。

目的変数となる購入頻度は,「日常的に購入する」 から「購入しない・わからない」までの 4 段階リッ カート尺度により質問している. このため回答は離 散的な変数となり, かつ, 頻度の多寡という順序を もつため順序ロジットモデルにより分析する。

一般的に購入頻度に関する質問項目では「週に 1 回」「月に 2-3 回」など具体的な数值を用いることが 多いが，本研究では「日常的に購入する」「たまに購 入する」などの主観的な表現を使用している。その 理由は（1）回答者の負担を軽減するため, (2) 具体 的な頻度は回答者ごとによって意味合いが異なるた め（たとえば，地場産農産物を日常食としていても
表 8. 個人属性に関する変数の定義と記述統計量

\begin{tabular}{|c|c|c|c|}
\hline 説明変数 & 定義 & 平均 & $\mathrm{SD}^{1)}$ \\
\hline $\begin{array}{l}\text { 地域社会 } \\
\text { へ貢献 }\end{array}$ & $\begin{array}{l}\text { Q : 住んでいる地域に貢献したい } \\
\text { 「強くそう思ら=4」から「全くそら } \\
\text { 思わない=0」の } 5 \text { 段階で回答 }\end{array}$ & 2.59 & 0.74 \\
\hline 性別 & 男性 $=1$, 女性 $=0$ & 0.49 & 0.50 \\
\hline \multirow[t]{2}{*}{ 居住年数 } & $\begin{array}{l}\mathrm{Q} \text { : お住まいの地域（自治会）の居 } \\
\text { 住期間 }\end{array}$ & 29.00 & 19.60 \\
\hline & $\begin{array}{l}1 \text { 年末満から } 50 \text { 年以上までを } 9 \text { 段階 } \\
\text { で回答（各ランクの中心值となる年 } \\
\text { 数をデータとして入力） }\end{array}$ & & \\
\hline $\begin{array}{l}15 \text { 歳以 } \\
\text { 下ダミ- }\end{array}$ & 15 歳以下の子あり $=1$, なし $=0$ & 0.29 & - \\
\hline \multirow[t]{2}{*}{$\begin{array}{l}\text { 健康志向 } \\
\text { 努力 }\end{array}$} & $\begin{array}{l}\text { Q : 自分の健康状態に関心をもち健 } \\
\text { 康管理に努めている }\end{array}$ & 1.96 & 0.80 \\
\hline & $\begin{array}{l}\text { 「当てはまる }=3 」 \text { から「当てはまら } \\
\text { ない=0」の } 4 \text { 段階で回答 }\end{array}$ & & \\
\hline $\begin{array}{l}\text { ボラン } \\
\text { ティア } \\
\text { 活動 }\end{array}$ & $\begin{array}{l}\text { Q : ボランティア活動への参加状況, } \\
\text { 「毎日〜週数回程度 }=4\rfloor \text { から「まっ } \\
\text { たくない }=0 」 の 5 \text { 段階回答 }\end{array}$ & 0.56 & 1.01 \\
\hline 世帯人数 & 同一住居の人数（複数世帯を含む） & 3.33 & 1.50 \\
\hline 世帯収入 & $\begin{array}{l}200 \text { 万円未満から } 1,400 \text { 万円以上ま } \\
\text { でを } 8 \text { 段階で回答（各ランクの中心 } \\
\text { 值となる金額のデータを百万円単位 } \\
\text { としてモデルに入力） }\end{array}$ & 5.75 & 3.25 \\
\hline
\end{tabular}

1) $\mathrm{SD}$ : 標準偏差

個人や家族の好みにより購入頻度的が異なり, 主観 的表現の方が回答者の異質性を考慮できるため), （3）主観的尺度での分析は，社会心理学や経済学の 分野ではごく一般的に用いられるため，である。と くに 2 番目の点については購入頻度の尺度に関して, 主観的な解釈の相違が極力起こらないよう，選択肢 の表現方法に留意した。

な拈，順序ロジットモデルは非線形であり，限界 効果を推計パラメーターから直接的に解釈すること はできない，そのため，分析結果では推計值に加え て各選択肢の限界効果の推計結果を含めることと した.

購入場所については, 購入有無ダミー (表 2 参照) を準備し, 各購入場所との交差項（購入有無ダミー ×各購入場所）を導入した.

説明変数については, 表 2 以外飞も一般的な個人 属性を含め 8 変数をモデルに用いた (表 8 参照)。こ れらは, 地産地消の消費に関連して地域社会との関 わりを示す属性，また，健康志向に対する消費者意 識を示す属性等であり，野洲市の市民意向調査の結 
果をそのまま利用したものである ${ }^{3}$ 、なお，表 2 の 説明変数「地元農業を応援」と表 8 の「地域社会へ 貢献」は類似した内容であり相関が懸念されたが, 確認したところ相関係数は 0.1 程度で問題はなかっ た ${ }^{4}$.

米・野菜・果物の分析結果を，それぞれ表 9 , 表 10 ，表 11 に示す。な拈，各表中に拈いて「購入し ない・わからない」は，便宜上「購入しない・不明」 と表現している。 まず商品毎にその限界効果の变化 を概観し，その後，各属性について 3 商品を横断的 に考察する。な扬，回答者には，すべて地場産農産 物であることを前提調査が実施されている.

(1) 米

「日常的に購入する」に抢ける限界効果の值は地元 小売店, その他の場所, 直売所, スーパーと購入場 所が上位を占めている。商品属性では，食味，価格， 安全の順で大きい，その他の場所とは，不特定な場 所であるが，回答では農家から直接購入，の記述が 多く見られた。拈米の購入に関して，すべての購入 場所は商品属性よりも影響度が大きく, 購入促進要
因となっている．この理由として，他の農産物とは 異なり購入時にお沙る商品の重さに要因があると考 えられるが後述する。商品属性では食味が限界効果 の值が一番大きく，地場産の扣米は安全よりも食味 に対して消費者選好が強いといら結果が示唆された.

「たまに購入する」場合の限界効果の值は，上位か らスーパー, 価格, 安全と続く。值の大きさから, 「日常的に購入する」場合と比べると，全体的に購入 に与える影響度が小さくなっている。また，上位の 属性の種類も変化し, 購入場所としてはスーパーた けとなっている.

個人属性（性別，健康志向努力なぞ）の限界効果 は，購入頻度に関わらず大きな変化はみられない。 また，統計的有意となった属性はなかった。

\section{(2) 野菜}

「日常的に購入」に抢汀る限界効果の大きい属性 は，順に価格，スーパー，食味，新鮮，応援と続く が，值に大差はない，一方，「たまに購入する」では 新鮮，スーパー，価格が上位となっており，安全， 応援，食味がその後に続く。野菜は米と比べると相

表 9. 限界効果の推定結果（米）

\begin{tabular}{|c|c|c|c|c|c|c|c|c|c|c|c|}
\hline \multirow{2}{*}{ （米） } & \multirow{2}{*}{\multicolumn{2}{|c|}{ 推計值 }} & \multicolumn{9}{|c|}{ 限界効果 } \\
\hline & & & \multicolumn{2}{|c|}{ 購入しない・不明 } & \multicolumn{3}{|c|}{ ごくたまに購入 } & \multicolumn{2}{|c|}{ たまに購入 } & \multicolumn{2}{|c|}{ 日常的に購入 } \\
\hline 説明変数 & 係数 & 標準誤差 & 限界効果 & $\mathrm{t}$ 值 & 限界効果 & $\mathrm{t}$ 值 & & 限界効果 & $\mathrm{t}$ 值 & 限界効果 & $\mathrm{t}$ 值 \\
\hline 安全 & 1.481 & 0.306 & -0.249 & $-5.811 * * *$ & -0.100 & -2.285 & $*$ & 0.131 & $5.225 * * *$ & 0.218 & $3.709 * * *$ \\
\hline 応援 & 0.709 & 0.320 & -0.131 & $-2.489 *$ & -0.037 & -1.193 & & 0.075 & $2.426 *$ & 0.093 & 1.866 \\
\hline 価格 & 1.847 & 0.313 & -0.287 & $-7.060 * * *$ & -0.143 & -3.015 & $* *$ & 0.135 & $5.234 * * *$ & 0.296 & $4.448 * * *$ \\
\hline 環境 & 1.168 & 0.646 & -0.181 & $-2.583 *$ & -0.102 & -1.152 & & 0.096 & $3.827 * * *$ & 0.187 & 1.371 \\
\hline 食味 & 2.233 & 0.347 & -0.318 & $-7.985 * * *$ & -0.189 & -3.640 & $* * *$ & 0.122 & $3.765 * * *$ & 0.385 & $4.858 * * *$ \\
\hline 信頼 & 1.016 & 0.300 & -0.183 & $-3.845 * * *$ & -0.057 & -1.661 & & 0.102 & $3.757 * * *$ & 0.137 & $2.731 * *$ \\
\hline 新鮮 & 0.156 & 0.316 & -0.031 & -0.506 & -0.004 & -0.357 & & 0.018 & 0.499 & 0.018 & 0.476 \\
\hline 購入有無×スーパー & 2.469 & 0.342 & -0.367 & $-7.323 * * *$ & -0.182 & -4.185 & $* * *$ & 0.140 & $4.780 * * *$ & 0.410 & $6.347 * * *$ \\
\hline 購入有無 $\times$ 直売所 & 3.121 & 0.452 & -0.332 & $-7.801 * * *$ & -0.290 & -5.787 & $* * *$ & 0.011 & 0.236 & 0.611 & $7.214 * * *$ \\
\hline 購入有無 $\times$ 地元小売店 & 5.225 & 1.174 & -0.309 & $-7.763 * * *$ & -0.365 & -7.754 & $* * *$ & -0.171 & $-4.191 * * *$ & 0.845 & $17.375 * * *$ \\
\hline 購入有無 $\times そ の$ 他場所 & 4.545 & 0.454 & -0.437 & $-9.757 * * *$ & -0.318 & -6.955 & $* * *$ & -0.050 & -1.568 & 0.805 & $17.727 * * *$ \\
\hline 栽培経験 & -0.297 & 0.190 & 0.061 & 1.551 & 0.005 & 0.656 & & -0.034 & -1.537 & -0.033 & -1.545 \\
\hline 地域社会へ貢献 & 0.234 & 0.191 & -0.048 & -1.221 & -0.004 & -0.606 & & 0.027 & 1.203 & 0.026 & 1.210 \\
\hline 性別 & -0.054 & 0.251 & 0.011 & 0.214 & 0.001 & 0.202 & & -0.006 & -0.214 & -0.006 & -0.214 \\
\hline 居住年数 & 0.013 & 0.008 & -0.003 & -1.673 & 0.000 & -0.660 & & 0.001 & 1.642 & 0.001 & 1.669 \\
\hline 15 歳以下 & -0.155 & 0.320 & 0.032 & 0.476 & 0.002 & 0.443 & & -0.018 & -0.483 & -0.017 & -0.495 \\
\hline 健康志向努力 & 0.049 & 0.158 & -0.010 & -0.309 & -0.001 & -0.283 & & 0.006 & 0.309 & 0.005 & 0.309 \\
\hline ボランティア活動 & 0.022 & 0.119 & -0.005 & -0.187 & 0.000 & -0.184 & & 0.003 & 0.187 & 0.002 & 0.187 \\
\hline 世帯人数 & 0.176 & 0.106 & -0.036 & -1.652 & -0.003 & -0.668 & & 0.020 & 1.638 & 0.019 & 1.652 \\
\hline 世帯収入 & -0.042 & 0.042 & 0.009 & 0.983 & 0.001 & 0.580 & & -0.005 & -0.978 & -0.005 & -0.980 \\
\hline $\mathrm{N}$ & 73 & & & & & & & & & & \\
\hline 対数尤度 & -31 & 15.53 & & & & & & & & & \\
\hline McFadden $\mathrm{R}^{2}$ & & 0.65 & & & & & & & & & \\
\hline
\end{tabular}

1）*****,*はそれぞれ $0.1 \%, 1 \% ， 5 \%$ の有意水準を示す.

2）説明変数の購入有無× (購入場所) は購入有無ダミーとの交差項であることを示す. 
表 10. 限界効果の推定結果（野菜）

\begin{tabular}{|c|c|c|c|c|c|c|c|c|c|c|c|c|c|c|}
\hline \multirow{3}{*}{$\begin{array}{c}\text { （野菜） } \\
\text { 説明変数 }\end{array}$} & \multirow{2}{*}{\multicolumn{2}{|c|}{ 推計値 }} & \multicolumn{12}{|c|}{ 限界効果 } \\
\hline & & & \multicolumn{3}{|c|}{ 購入しない・不明 } & \multicolumn{3}{|c|}{ ごくたまに購入 } & \multicolumn{2}{|c|}{ たまに購入 } & & \multicolumn{3}{|c|}{ 日常的に購入 } \\
\hline & 係数 & 標準誤差 & 限界効果 & $\mathrm{t}$ 值 & & 限界効果 & $\mathrm{t}$ 值 & & 限界効果 & $\mathrm{t}$ 值 & & 限界効果 & $\mathrm{t}$ 值 & \\
\hline 安全 & 1.085 & 0.208 & -0.096 & -4.935 & $* * *$ & -0.159 & -4.784 & $* * *$ & 0.135 & 5.198 & $* * *$ & 0.119 & $4.399 *$ & $* * *$ \\
\hline 応援 & 1.243 & 0.228 & -0.096 & -5.457 & $* * *$ & -0.182 & -5.149 & $* * *$ & 0.123 & 5.510 & $* * *$ & 0.155 & 4.261 * & $* * *$ \\
\hline 価格 & 1.531 & 0.213 & -0.124 & -6.250 & $* * *$ & -0.218 & -6.332 & $* * *$ & 0.154 & 5.977 & $* * *$ & 0.188 & $5.565 *$ & $* * *$ \\
\hline 環境 & 1.231 & 0.588 & -0.078 & -3.276 & $* *$ & -0.178 & -2.452 & $*$ & 0.075 & 2.253 & $*$ & 0.180 & 1.523 & \\
\hline 食味 & 1.253 & 0.304 & -0.087 & -4.932 & $* * *$ & -0.183 & -4.363 & $* * *$ & 0.098 & 4.568 & $* * *$ & 0.172 & 3.082 & $* *$ \\
\hline 信頼 & 0.713 & 0.242 & -0.060 & -3.249 & $* *$ & -0.108 & -2.855 & $* *$ & 0.087 & 3.581 & $* * *$ & 0.081 & 2.475 & $*$ \\
\hline 新鮮 & 1.610 & 0.212 & -0.169 & -6.065 & $* * *$ & -0.209 & -6.398 & $* * *$ & 0.222 & 6.764 & $* * *$ & 0.157 & $6.439 *$ & $* * *$ \\
\hline 購入有無×スーパー & 1.632 & 0.237 & -0.147 & -5.793 & $* * *$ & -0.225 & -6.148 & $* * *$ & 0.188 & 6.274 & $* * *$ & 0.184 & $5.539 *$ & $* * *$ \\
\hline 購入有無×直売所 & 0.695 & 0.274 & -0.059 & -2.791 & $* *$ & -0.105 & -2.457 & $*$ & 0.086 & 3.026 & $* *$ & 0.078 & 2.171 & $*$ \\
\hline 購入有無×地元小売店 & 1.737 & 0.867 & -0.091 & -3.959 & $* * *$ & -0.229 & -2.911 & $* *$ & 0.027 & 0.235 & & 0.294 & 1.428 & \\
\hline 購入有無×その他場所 & 1.562 & 0.682 & -0.088 & -4.019 & $* * *$ & -0.214 & -3.012 & $* *$ & 0.050 & 0.690 & & 0.252 & 1.633 & \\
\hline 栽培経験 & -0.264 & 0.141 & 0.026 & 1.832 & & 0.039 & 1.844 & & -0.040 & -1.840 & & -0.025 & -1.860 & \\
\hline 地域社会へ貢献 & 0.258 & 0.146 & -0.025 & -1.730 & & -0.038 & -1.726 & & 0.039 & 1.727 & & 0.024 & 1.746 & \\
\hline 性別 & 0.046 & 0.193 & -0.005 & -0.236 & & -0.007 & -0.237 & & 0.007 & 0.236 & & 0.004 & 0.237 & \\
\hline 居住年数 & 0.006 & 0.006 & -0.001 & -0.995 & & -0.001 & -1.000 & & 0.001 & 0.999 & & 0.001 & 0.999 & \\
\hline 15 歳以下 & 0.120 & 0.252 & -0.012 & -0.486 & & -0.018 & -0.474 & & 0.018 & 0.486 & & 0.012 & 0.468 & \\
\hline 健康志向努力 & 0.261 & 0.120 & -0.026 & -2.112 & $*$ & -0.038 & -2.114 & $*$ & 0.039 & 2.111 & $*$ & 0.025 & 2.148 & \\
\hline ボランティア活動 & 0.109 & 0.097 & -0.011 & -1.110 & & -0.016 & -1.113 & & 0.016 & 1.113 & & 0.010 & 1.114 & \\
\hline 世帯人数 & -0.057 & 0.081 & 0.006 & 0.707 & & 0.008 & 0.707 & & -0.009 & -0.706 & & -0.005 & -0.709 & \\
\hline 世帯収入 & 0.007 & 0.032 & -0.001 & -0.214 & & -0.001 & -0.214 & & 0.001 & 0.214 & & 0.001 & 0.214 & \\
\hline $\mathrm{N}$ & 73 & 36 & & & & & & & & & & & & \\
\hline $\begin{array}{l}\text { 対数尤度 } \\
\text { McFadden } R^{2}\end{array}$ & -47 & $\begin{array}{r}77.64 \\
0.52\end{array}$ & & & & & & & & & & & & \\
\hline
\end{tabular}

1）***，***はそれぞれ $0.1 \% ， 1 \% ， 5 \%$ の有意水準を示す.

2）説明変数の購入有無×（購入場所）は購入有無ダミーとの交差項であることを示す。

表 11. 限界効果の推定結果（果物）

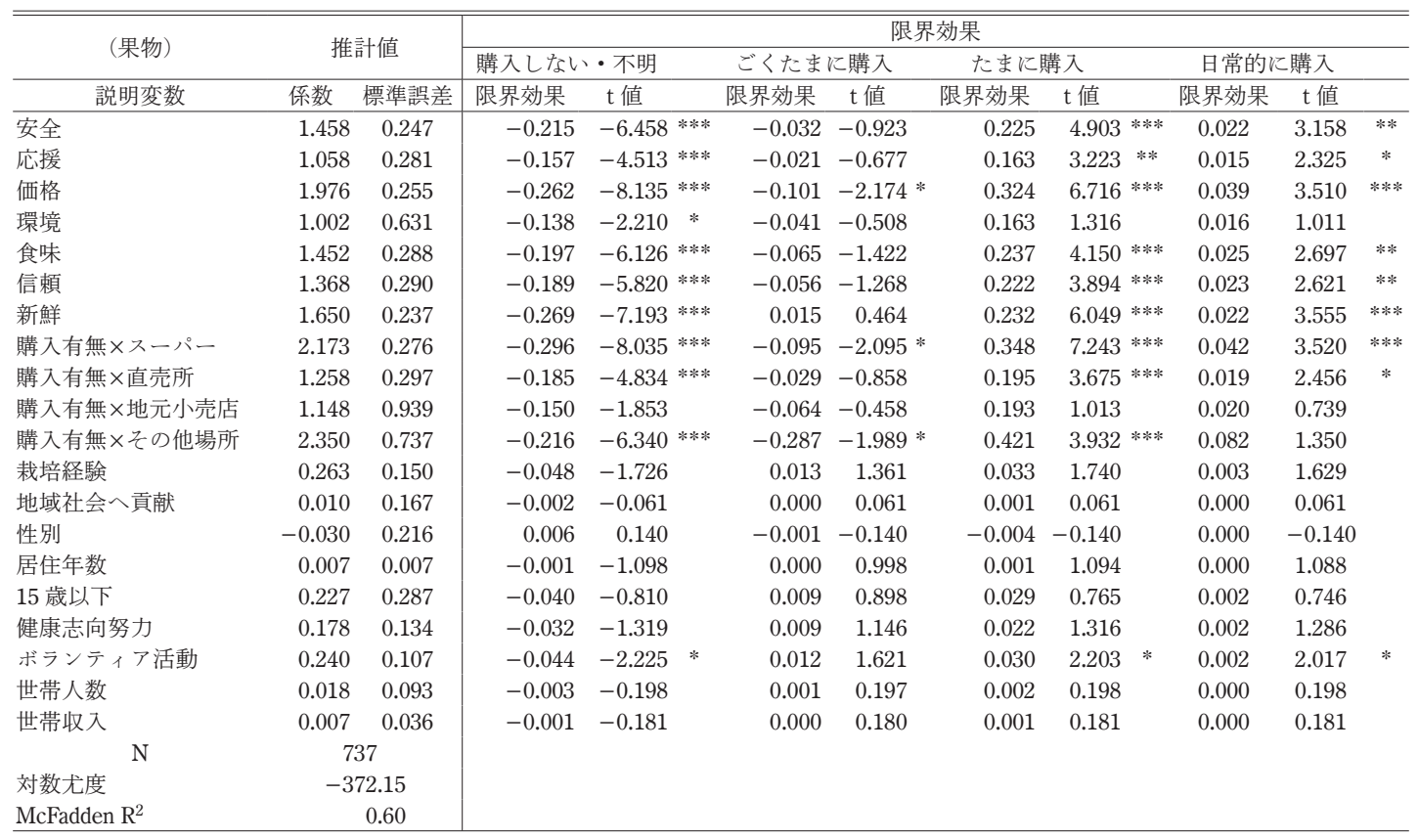

1）*****,*はそれぞれ $0.1 \%, 1 \%, 5 \%$ の有意水準を示す.

2）説明変数の購入有無× (購入場所) は購入有無ダミーとの交差項であることを示す. 
対的に購買頻度が高く，扔手頃価格に対する消費者 選好が示唆されている.

購入場所としてスーパーと直売所が有意となった が,「日常的に購入」,「たまに購入する」とも限界効 果の值はスーパーの方が大きい. 野洲市内の販売店 に打ける事前調査では, 野菜の品揃兄に関しては直 売所の方が充実している. しかし, 商品属性以外に も，スーパーに扣ける他の利便性が選択に影響して いる可能性が考光られる.

個人属性では, 健康志向努力の久が有意となった. 健康と野菜との関係が示唆される.

\section{(3) 果物}

「日常的に購入」に扔ける限界効果は, 順に, スー パー, 価格, 食味, 信頼, 安全, 新鮮となっている. 購入場所はスーパー以外にも直売所が有意となって いる. 商品属性では, 野菜と同様に価格が 1 位となっ ているが，その限界効果の值からは，購入に対する 影響力は小さいと考觉られる.

「たまに購入する」場合の限界効果の值は, 順に, その他の場所, スーパー, 価格, 食味, 新鮮と続く. その他の場所を選択した回答者（表 6 参照）は少な く, 購入場所として農協の記述も見られたが, ここ では議論の対象にしない。

購入頻度増加にともなら限界効果の変化の大きさ は, 米とは逆に「日常的に購入する」方が「たまに 購入する」場合と比べると, 全体的に購入に与える 影響度が低くなっている.

個人属性については, ボランティア活動が唯一有 意を示した.

以上の結果を踏まえ, 地場産農産物の購買行動を 規定する属性に関して 3 商品を横断的に考察する.

\section{(4) 購入理由}

表 9 , 表 10 , 表 11 が示す通り, 多くの変数が地 場産農産物の購買を有意に規定する要因として特定 されたが, 個々の説明変数を「たまに購入」,「日常 的に購入」に着目すると, 商品によりその傾向は異 なっている. 具体的には, 米では食味や価格である こと, 野菜ではさらに新鮮であることが, 統計的有 意性や全体的な係数值から解釈できる. 米は貯蔵可 能であるため, 消費者は鮮度を重視しないと推測で きることであるが，今回の結果はそのことが定量的 に裏付けられたものと理解できる. 果物では両方の
購入頻度に扔いて，括手頃な価格が購入促進への影 響に対して相対的に大きいという結果を示した.

各商品に共通する要因に抏いて, 価格が限界効果 の大きさ順で上位にあり，価格に対する消費者選好 の程度の強さを示唆している.「日常的に購入」で は，環境保全への貢献がすべての商品で有意ではな い. 表 5 の商品別購入理由の結果も, 地域の環境保 全に貢献を選択した回答者の割合が小さくなってい る. 食味については，すべての商品について有意で あり, 購入頻度の多い消費者にとっては, 係数の符 号が正であることから, 地場産農産物の購入促進要 因となりらる。なかでも，米にとって，食味は最も 重要な商品属性として分析されている。 その他, 安 全や信頼もすべての商品に执いて有意となっている.

地元農家を応援したいからといら購入理由では, 米の一部の購入頻度を除き，すべての商品で有意で あり限界効果の值も正となっている. 地場産農産物 の消費によって地元農業を応援している傾向が示唆 される.

以上のよらな購入理由から, 一般の農産物よりも 地場産が選好されると考光られるが，次に，それら がどこで購入される傾向にあるのかを検討する.

\section{（5）購入場所と個人属性}

購入場所ではスーパーが野菜と果物の購入促進の 程度に対して他の購入場所よりも大きい影響を示し ている，実際の買い物では，野菜や果物だけを買い に行くことは少なく，他の日用品とともに購入され るのが日常である。消費者にとって，スーパーは， 他の商品に対する品揃えの豊富さ, 価格の手頃さ, 近年のショッピングモール内での立地等, 商品属性 以外の利便性があり，これらを総合的に勘案した結 果の選好が, 野菜と果物では, 身近な購入先のなか でも，スーパーであると考光られる。

米については「日常的に購入」の購入場所として, 地元小売店の限界効果の值が 1 位となっている. 地 元小売店での購入は，重い米袋を運ばずとも自宅玄 関先まで配達してくれることが多い. 価格もスーパー と遜色がなければ，配達のような地元密着サービス が購入促進に寄与していると考光られる. 表 1 から も, 回答者の約 $50 \%$ が 60 歳以上であり, 米の購入 先として, 自宅へ配達可能な地元小売店に対する選 好が示された。 このように，スーパーでは買い物で 
の利便性, 地元小売店は商品配達など, 直接の商品 属性以外の要因により, 普段から利用する購入先と して，主に規定されていると考光られる。

表 8 亿示した個人属性で, いずれかの商品で有意 になった変数はボランティア活動, 健康志向努力の 2 変数であった。 ボランティア活動は果物にの反有 意を示した. 限界効果の值を他の有意な変数と比較 しても目立って小さく，相対的に購入促進効果への 影響は限られるものと推測される. 健康志向努力は, 野菜にの久有意である. 健康志向努力は, 野洲市の 調査用紙によれば「自分の健康状態に関心をもち, （中略）健康管理に努めている」ことについて自分が あてはまるかどらかを問ら質問である，日常的な健 康意識の高低が，地場産野菜の購入に少なからず影 響していることになるが，その程度はボランティア 活動と同様に小さい.

上記以外の個人属性は, どの商品に扔いても有意 ではない結果となった。

\section{（6）栽培経験}

既述のごとく，栽培経験はいずれの商品において も有意とはならなかった．藤島・岩崎（2010）の述 べている, 産直志向を高める等の地場産農産物の購 入促進に間接的ではあるが，農業経験は有利に作用 する属性，との結果には至らなかった。

栽培経験が地場産農産物の購入促進に有意を示さ なかった理由として, 野洲市の地域性が考兄られ る。表 7 を見ると, 栽培経験を有していても農家の ような農産物の自給自足が可能な回答者が存在し, さらに家庭菜園でも自宅の庭や市民農園を利用して おれば自給可能な野菜が生産可能と考えられる。こ のため, 野洲市に和ける栽培経験は, 農産物の一部 が自給可能となる可能性があり, 販売店での購買行 動に結びつきにくいことが考光られる，野菜では， 購入頻度の多い層での栽培経験の限界効果は負を示 しており, 購買に対しては抑制要因となることが推 測される。しかし，本調査での質問文は「あなたの 農作物の栽培作業の経験について, 近い項目を $1 つ$ 選んでください」と設定して扣り，その選択肢も表 2 で示したと扣りであることから, 経常的に栽培を しているか否かは不明である.

以上のよらな理由から，栽培経験が有意とならな かったと考えるが, 経験の有無だけではなく, 調査
地域によっては, 栽培継続の有無や栽培の目的も地 場産農産物の購入促進に影響する可能性があり, 今 後の研究課題として指摘される。

\section{（7）小括}

「日常的に購入」する人にとっては, 身近に利用し ている購入場所でも, 米は地元小売店, 野菜と果物 はスーパーが，相対的に購入促進に対して最も大き く貢献していることが示唆された，その理由として， 米では $5 \mathrm{~kg}, 10 \mathrm{~kg}$ 等の米袋を運搬するのは困難で あり自宅配達可能な地元小売店が選好される可能性 がある．野菜や果物については，地場産農産物の品 揃えに関して直売所はスーパーよりも豊富であるが, 他の生活必需品とともに購入する消費者にとっては, 地場産農産物であってもスーパーで購入する傾向に ある、これらは，一般の農産物にもあてはまる選択 理由であるが，（4）で検討した購入理由により，地 場産が選択されることになる。

以上の考察から，「日常的に購入する」人にとって の商品ごとの販売促進要因を購入理由と購入場所か ら整理すると，米では「扔いしくて安全で，和手頃 価格の拈米を地元小売店で販売」することである. 野菜は,「おいしくて新鮮で扣手頃価格の野菜をスー パーで販売」することが購入促進につながる. 果物 では，「括いしくて信頼でき，括手頃価格の果物を スーパーで販売」することである.

\section{6. 結論}

本研究では, 地場産農産物の購入要因について, 米, 野菜, 果物を商品別に分析した. 購入理由や購 入場所，栽培経験なぞについて，滋賀県野洲市の一 般成人を対象に郵送アンケートにより収集したデー タを順序ロジットモデルにより推定した. その結果, 購入理由や購入場所については, 各商品に固有の要 因がありつつも，全体に共通する要因もあることが 明らかとなった。

購入要因別では, 商品属性に関して, 米が食味や お手頃価格, 安全が, 野菜では新鮮や価格, 食味が, 果物では, 価格や食味, 新鮮が限界効果の值の大き さで上位を占めた．また，地元農家への応援という 購入理由では，米の一部を除き，すべての商品で有 意となった。このことから，購入者は地域の生産者 をある程度意識し，その農産物の購入を介して応援 
していることが示唆された.

地域環境保全への貢献を挙げている回答者は, 各 商品とも全体の 2-3\%程度であり極めて低い. 捉光 万によっては, 地場産農産物の生産が地域の環境保 全に役立つことを教育や告知などにより広めれば, 今後の購入促進が期待できる.

栽培経験については，すべての商品で有意となら なかった。野洲市に拈いては, 栽培経験は, 栽培に より農産物の一部が自給自足されている可能性があ り, 地場産農産物の購入に結びつかないことも考光 られる。しかし, 今回の調査では栽培経験者が野菜 等の栽培を継続しているか否かは不明であり, 今後 の研究課題である.

個人属性では, ボランティア活動が果物に, 健康 志向努力が野菜に拈いてのみ有意であった. しかし， 日常的に購入する層にとって, ボランティア活動の 限界効果の值が相対的に小さく購入促進効果への影 響は少ないと考えられる. 健康志向では, 野菜の消 費と健康との結びつきが消費者意識において醸成さ れていることが示唆されたが，ボランティア活動と 同様に限界効果の值は小さい.

野洲市の市民意向調査から得られた年齢・性別・ 収入・世帯人数などの人口動態要因については, い ずれの商品でも有意な結果は得られなかった。 しか し，実際の分析では，その一部を利用しただけであ り, 今後, 野洲市地域の特性も考慮したさらなる調 査により新たな知見が得られる可能性がある.

冒頭でも述べたよらに, 持続可能な社会の実現に おいて, 地場産農産物を購入することは消費の面で の実現手段の一つである. それはSDGs の目標 12 を 達成するためのアクションでもある. 目標 12 は「つ くる責任 つから責任」とも表現されており, 農家 が環境や安全に配慮しながら農産物を生産し, 消費 者がこれを積極的に消費することで, 地域の環境保 全や経済活性化につながり, SDGs の目指す持続可 能な社会の実現へ向けての好循環が生まれると考光 られる。

最後に, 本研究の限界・課題として内生性の問題 を指摘しておきたい. すでに述べたよらに，本研究 の推定モデルに拈ける購入場所に関する变数は, い ずれも地場産農産物の購入有無との交差変数となっ ている. 一般に購買行動は, 財の属性以外にも個人
属性や地域属性などにも規定されることから, 潜在 的な内生性が指摘される. データ上の制約から, 本 研究ではこれらを外生的に取り扱っているが，今後 の発展的研究では, 購買行動の内生性を明示的に取 り扱らことを課題として検討していきたい.

本研究の分析は, 滋賀県野洲市を対象としたアン ケート調査を基に実施したものである，本研究の分 析結果を踏まえつつ, 今後は他の自治体やょり広範 囲な調査分析を扣こない，より一般性の高い知見を 導出することを直近の課題としたい.

\section{謝辞}

当研究は, 滋賀県野洲市との共同研究により実現 したものです。特に, 野洲市企画調整課の皆様には ご支援ならびにご理解を賜り深謝いたします。

\section{注}

1 消費者庁（2018）の発行する「エシカル消費ってなあに?」 によれば地産地消もより良い社会に向けた具体的アクション の一つである，と説明している.

2 購入理由の選択肢の回答数を 3 つまでと限定した。これは, 過去の同様な調査において回答者の選択数に大きなバラッキ があり, 重要な購入理由に絞り込むためである. しかし，上 限を設けない場合と比べ，すべての理由を分析結果に反映で きない可能性がある.

3 野洲の市民意向調査では順序尺度であるリッカート尺度が多 く使用されている．本分析では，これを間隔尺度として扱っ ており，この場合，選択肢間における等間隔性の問題や測定 範囲に打ける限界はあるが, Carifio, J., \& Perla, R.（2008）に よれば，測定対象が連続的な特性をもち，5段階程度の選択 肢があれば実用上大きな問題のないことが経験的・実証的に 明らかにされている.

4 ピアソンの相関検定（両側）ではいずれも有意であった．本 調査では,「地元農業を応援」は農産物の購入者を対象にし た回答であるため, 主たる動機は購入のための利己的動機で ある. しかし, その過程に抢いて付随的に利他的動機も観測 されていると考えられる. 他方, 「地域社会へ貢献」は主に 利他的動機によるものであり，この主たる動機の相違が相関 を低くしていると考えられる.

\section{引用文献}

大庭隆嗣・平野達朗・栗原伸一（2006）「地元産農産物に対す る消費者選好の因果構造」『農村計画学会誌』25:413418. https://doi.org/10.2750/arp.25.413

消費者庁（2017）「倫理的消費」調査研究会編『「倫理的消費」 
調查研究会取りまとめ』, https://www.caa.go.jp/policies/ policy/consumer_education/consumer_education/ethical_ study_group/pdf/region_index13_170419_0002.pdf (2019 年 8 月 12 日参照).

消費者庁（2018）「エシカル消費ってなあに? 」, https:// www.caa.go.jp/policies/policy/consumer_education/public awareness/ethical/pdf/ethical_180409_0001.pdf（2019 年 6 月 4 日参照).

徳永翔大 ・後藤尚弘・九里徳泰（2015）「地産地消・旬産旬消 の環境配慮行動の要因に関する分析」『環境システム研究 論文集』43：II _329- II _337． https://doi.org/10.2208/ jscejer.71.II_329

内藤重之（2006）「地産地消運動の展開と意義」橋本卓爾・大 西敏夫・藤田武弘・内藤重之編著『食と農の経済学』ミネ ルヴァ書房.

西村武司・松下京平・藤栄 剛（2012）「生物多様性保全型農 産物に対する消費者の購買意志」『フードシステム研究』 18(4) : 403-414. https://doi.org/10.5874/jfsr.18.403 藤島廣二・岩崎邦彦（2010）「農産物の産直を志向する消費者 の特性」『農村研究』110:13-22.

牧山正男・三富良正（2004）「地場産農産物購入者の属性と意
識」『農村計画論文集』6:121-126. https://doi.org/10.2750/ arp.23.23-suppl_121

山本康貴・栈敷孝浩・澤内大輔・増田清敬・所 説夫 ・岩本博 幸（2009）「インショップ併設スーパー来店客を対象とし た地場農産物の消費者評価分析」『北海道農業経済研究』 14(2) : 77-83.

Brown, C. (2003) Consumers' preferences for locally produced food: A study in southeast Missouri, American Journal of Alternative Agriculture 18: 213-224.

Carifio, J. and R. Perla (2008) Resolving the 50-year debate around using and misusing Likert scales, Medical education 42(12): $1150-1152$.

Micheletti, M. (2003) Political Virtue and Shopping Individuals, Consumerism, and Collective Action, New York: Palgrave Macmillan.

Thilmany, D., C. A. Bond, and J. K. Bond (2008) Going Local: Exploring Consumer Behavior and Motivations for Direct Food Purchases, American Journal of Agricultural Economic 90: 1303-1309.

Zepeda, L. and J. Li (2006) Who buys Local Food?, Journal of Food Distribution Research 37(3): 1-11. 